\title{
AN OBJECT-ORIENTED SOFTWARE DESIGN TOOL USING AUTOMATED HoQ AND AHP FOR TRACING AND PRIORITIZING SYSTEM REQUIREMENTS ${ }^{+}$
}

\author{
Ahmed A. Attia ${ }^{*}$, Mohamed A. Soliman ${ }^{* *}$ \\ ${ }^{* *}$ Remote Sesnsing \& Space Sciences Authority, Cairo, Egypt \\ ${ }^{*}$ Computers \& Systems Eng. Dept., Zagazig University, Zagazig, Egypt
}

\begin{abstract}
:
It has been widely acknowledged that software products should be developed based on customer requirements in order to achieve a high level of software quality and customer satisfaction. Tracing customer requirements and their impacts through the software development life cycle is not a well-explored area. In this paper, a framework is presented that uses quality function deployment (QFD) to trace customer requirements explicitly through various phases, such as requirements elicitation, analysis, and design in object-oriented software development, by assessing their impact on software artifacts of the next stages. QFD helps visualize the complete tracing from customer requirements to class designs. Degrees of impact are clearly calculated and presented in QFD automatically using a simple software (an excel sheet). The Analytical Hierarchy Process (AHP) is used to prioritize and calculate the importance index of customer requirements and their impact on design stages. In traditional QFD. the correlation between customer requirements and technical requirements is determined by the members of a design team using linguistic expressions (e.g. weak, average, and strong). These linguistic terms are then scaled into crisp values (e.g. 1-3-9) for the ranking of each alternative. This crisp assessment for correlation evaluation in QFD analysis has difficulty coping with uncertainty among design team members. Therefore, fuzzy sets are adapted in this paper. An object-oriented software design tool example is developed to illustrate and validate the framework.
\end{abstract}

KEY WORDS: Analytical hierarchy process (AHP), house of quality (HoQ), fuzzy sets, object-oriented software design, software quality function deployment (SQFD), traceability, customer requirements, system requirements, subsystem requirements, module requirements, remote sensing micro satellites.

\section{CONCEPTION D'OUTILS LOGICIELS ORIENTEE-OBJET A L'AIDE DE AHP AUTOMATIQUE ET HOQ POUR DES RECHERCHES ET SYSTEME ORDRE DE PRIORITE}

\section{RÉSUMÉ :}

Il a été largement reconnu que les produits logiciels devraient être développés en fonction des besoins du client afin d'atteindre un niveau élevé de qualité des logiciels et la satisfaction du client. Tracer les exigences des clients et de leurs impacts à travers le cycle de vie du développement logiciel n'est pas un endroit bien exploré. Dans cet article, un cadre est présentée que le déploiement de la fonction qualité (QFD) pour tracer les exigences du client explicitement par des phases diverses, telles que élicitassions des exigences, l'analyse et de conception dans le développement logiciel orienté objet, en évaluant leur impact sur les artefacts logiciels de la les prochaines étapes. QFD permet de visualiser la traçabilité complète des besoins des clients à des conceptions de classe. Degrés d'impact sont clairement calculés et présentées dans QFD automatiquement en utilisant un logiciel simple (une feuille Excel). L'analyse hiérarchique (AHP) est utilisé pour établir des priorités et calculer l'indice de l'importance des besoins des clients et de leur impact sur les stades de conception. En QFD traditionnels. la corrélation entre les exigences des clients et des exigences techniques est déterminé par les membres d'une équipe de conception en utilisant des expressions linguistiques (par exemple, faible, moyenne et forte). Ces termes linguistiques sont ensuite mis à l'échelle en valeurs nettes (par exemple 1-3-9) pour le classement de chaque solution. Cette évaluation nette pour l'évaluation de correspondance figurant à l'analyse QFD a du mal à faire face à l'incertitude chez les membres de l'équipe de conception. Par conséquent, sousensembles flous sont adaptés dans le présent document. Un exemple de logiciels orientés objet la conception d'outils est développée pour illustrer et valider le cadre.

MOTS CLES: processus de hiérarchie analytique (AHP), maison de qualité (Hoq), ensembles flous, la conception de logiciels orientés objet, déploiement de la fonction des logiciels de qualité (SQFD), la traçabilité, les exigences du client, la configuration système requise, les exigences du sous-système, les exigences de module, de la télédétection microsatellites.

\footnotetext{
* recieved:7/11/2010, accepted:9/1/2011 (origional Paper)

** Contact author (0101811863)
} 


\section{INTRODUCTION}

Traditionally, traceability analysis provides linkages between requirements and design items. Although the linkage is necessary, it is not enough to develop software products with high customer satisfaction.

A tradeoff analysis that can be done to select a suitable requirements prioritization method and the results of trying one method, AHP, in a case study is described [1], [2]. AHP was developed by Thomas Saaty and applied to software engineering by Joachim Karlsson and Kevin Ryan in 1997 [3], [4], and [5]. AHP is a method for decision making in situations where multiple objectives are present. This method uses a pair-wise comparison matrix to calculate the relative importance of security software requirements. By using AHP, the requirements engineer can also confirm the consistency of the result. AHP can prevent subjective judgment errors and increase the likelihood that the results are reliable.

The limitations of QFD house of quality in its original form and also the advantages of automating it are identified [6]. The construction of the house of quality is simplified by creating it on Microsoft Excel. The standard format of the automated house of quality (AHOQ) created has been tested to be reusable and extendable for multiple applications. It saves time and effort as well as allows for automatic calculations of absolute and relative values.

A method for mapping and prioritizing customer requirements into functional features and technical modules to optimize market performance is introduced [7]. Although the quality of a product can be dramatically improved through a QFD exercise, the traditional crisp scoring approach has a major drawback. To over- come this problem, fuzzy scoring for linguistic terms is proposed. The implementation case of a low-end digital camera design shows that the result of the proposed fuzzy QFD model can reflect the certainty level of an evaluation term, which is designated for each correlation of customer requirements and technical requirements considered in design.

How different requirements have different impacts on design items are analyzed [8]. A design item that is impacted by more important requirements deserves more attention than a design item that is impacted by fewer important requirements. Otherwise, if more resources are given to design items with small impacts on the requirements, it is a waste of limited resources. It addresses the issue of requirements traceability by assessing the degrees of impact with the help of quality function deployment (QFD). QFD, which was developed more than 30 years ago in Japan, is a methodology that incorporates the voice of the customer into a product, and it is an excellent method for assuring that customers receive high quality products [9]. QFD is a process that transforms desires of the customer at all levels into the implementation of a product. Instead of focusing solely on defect prevention and elimination like traditional process improvement initiatives, QFD focuses on both minimizing the number of defects (customer dissatisfaction) and maximizing value (customer satisfaction). Software quality function deployment (SQFD) is the application of QFD to software production, which focuses on improving the quality of both the software development process and the product [10]. The ultimate goal is no longer zero-defect software, but rather good software that provides very high customer satisfaction. SQFD has 
been applied to the improvement of software quality focusing on three phases of the software development life cycle. It uses a set of house of quality (HoQ) matrices to translate customer requirements into system, subsystem, and class requirements.

This paper addresses the issue of requirements traceability by assessing the degrees of impact with the help of quality function deployment (QFD), House of Quality (HoQ). Analytical Hierarchy Process (AHP) is used for the purpose of prioritizing the customer requirements during implementing the House of Quality. The house of quality has been automated using an excel sheets thereby saving effort and time by using automated calculations. Besides, it gives the possibility of adding more customer or technical requirements to the HoQ matrix. Fuzzy sets and the concept of linguistic variables are adapted in this research. This model uses a four-phase set of house of quality (HoQ) matrices to translate customer requirements into system, subsystem, module and component requirements. An application example about developing an object oriented software tool for designing of a micro satellite system is used. The priorities resulting from the above has been used to prioritize the methods of design in the application program. The structure of classes corresponding to each phase has been shown.

\section{A NEW METHODOLOGY}

During the design and development phases, it is helpful to know what the most important design items are in terms of their correlation with the requirements. Thus, a priority assessment framework is provided to help find the important design items phase by phase. In this framework, HoQ incorporates customer requirements into multiple phases of the object-oriented software development life cycle, including system design, subsystem design, and module class design. There has been little research, however, on the traceability of customer requirements through objectoriented software developments. QFD seems to be a natural solution to this problem because it was developed to transform the voice of customer into designs. The advantage of using HoQ (from QFD) in this methodology is that it traces customer requirements from the very beginning to object module design. As a result, it is easier for both customers and developers to visualize which module is designed to reflect which set of requirements and to what extent these requirements are implemented. Based on the assessment result, limited resources can be allocated to more important design items and the resultant software product will achieve a higher level of customer satisfaction.

\section{QFD METHODOLOGY FOR OBJECT-ORIENTED SOF WARE DEVELOPMENT; AN INTGRA-TED FRAMEWORK}

An integrated framework (see Fig. (1)) for the application of QFD to object-oriented software development is developed. There are four phases in this development life cycle that this framework covers. They are:

Phase 1: Customer requirements are deployed to both the product functions and the quality factors of the whole system. The fuzzy sets are used in this phase instead of crisp numbers.

Phase 2: The product characteristics, which reflect the voice of customers, obtained from the previous phase are deployed into the important subsystem functions and subsystem constraints.

Phase 3: The most important functions and constraints of the modules are identified. The subsystem characteristics from the pre- 
An Object-Oriented Software Design Tool Using Automated Hoq And Ahp For Tracing And Prioritizing System Requirements.

Attia and Soliman

vious phase are deployed to these functions and constraints.

Phase 4: Module functions and module constraints are deployed into component functions and component constraints in this phase.

In order to provide traceability, the final outputs from each phase are used as the inputs for the next phase matrices. In this manner, customer requirements are incorporated into the whole system.

There are three types of matrices used in this framework to help in reflecting traceability, namely, quality house of quality (Q-HoQ), functional house of quality (FHoQ), and the design point analysis matrix. Quality and functionalities are the two major issues affecting the degree of customer satisfaction. Thus, this paper tries to relate customer requirements with each one of the two using HoQs. The HoQ relating customer requirements with the

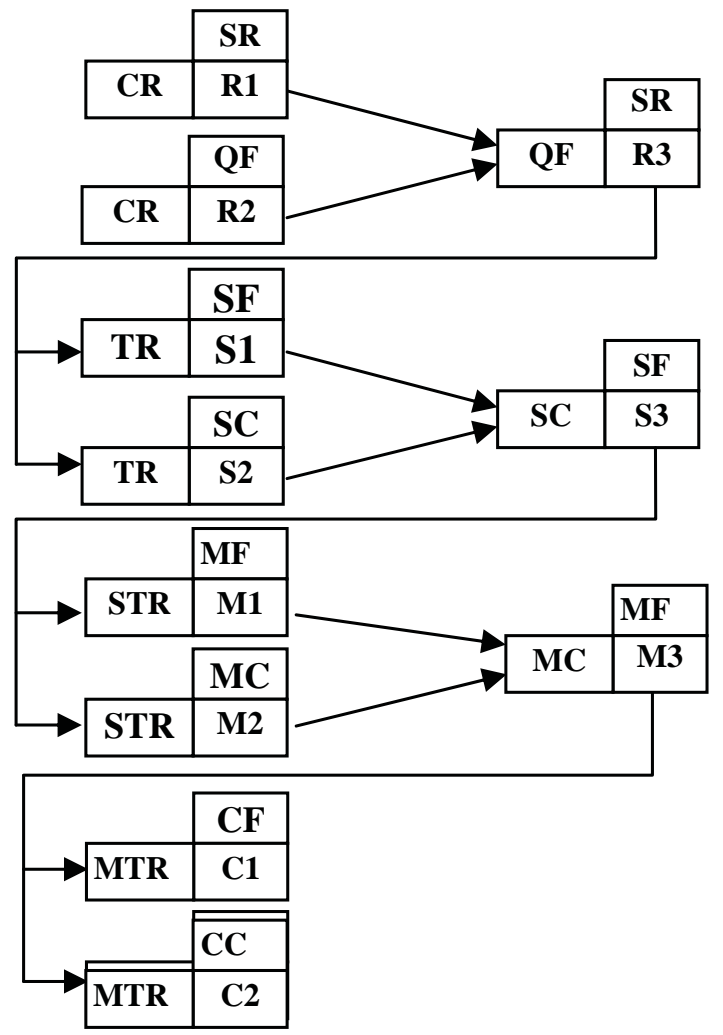

quality factors is given the name Q-HoQ; similarly, the HoQ relating customer requirements with the functionalities is given the name F-HoQ. The design point analysis matrix is then used to combine the quality factors and functionalities, both of which now have weight values reflecting the impacts from the customer requirements.

In Figure 1, the matrices R2, S2, M2 and C2 are Q-HoQs; the matrices R1, S1, M1 and C1 constitute F-HoQs; and the matrices R3, S3 and M3 are of the type of design point analysis matrix. The customer requirements serve as an input into R1 (F-HoQ) and R2 (Q-HoQ) requirement elicitation matrices. The results of these two requirements elicitation matrices serve as inputs for the R3 matrix. Results of the R3 matrix are used to combine the product functions and quality factors into one set of subsystem-level requirements, which are carried over to Phase 2 of the development life cycle where similar steps are taken.

\section{Phase 1: Requirements Elicitation Phase}

$\mathrm{CR}=$ Customer Requirements

$\mathrm{SR}=$ System Requirements

$\mathrm{QF}=$ Quality Factors

\section{Phase 2: Subsystem Design Phase}

$\mathrm{TR}=\mathrm{SR}+\mathrm{QF}$ (From previous phase)

$\mathrm{TR}=$ Technical Requirements

$\mathrm{SF}=$ Subsystem Functions

$\mathrm{SC}=$ Subsystem Constraints

\section{Phase 3: Module Design Phase}

$\mathrm{STR}=\mathrm{SF}+\mathrm{SC}$ (From previous phase)

STR $=$ Subsystem Technical Requirements

$\mathrm{MF}=$ Module Functions

$\mathrm{MC}=$ Module Constraints

\section{Phase 4: Component Design Phase}

$\mathrm{MTR}=\mathrm{MF}+\mathrm{MC}$ (From previous phase)

MTR $=$ Module Technical Requirements

$\mathrm{CF}=$ Component Functions

$\mathrm{CC}=$ Component Constraints 


\section{CLASS DIAGRAM}

The design phases of the object oriented software system will be reflected on the class diagram [11] as shown in Fig. (2). It shows the systems and subsystem classes, similarly module and component classes can represented. The instant variables of the system class are objects of the subsystems classes. The instant variables of the subsystem class are objects of the module classes. The methods of each module class are executed according to the weighted priorities of each module function and module constraint in the application program.

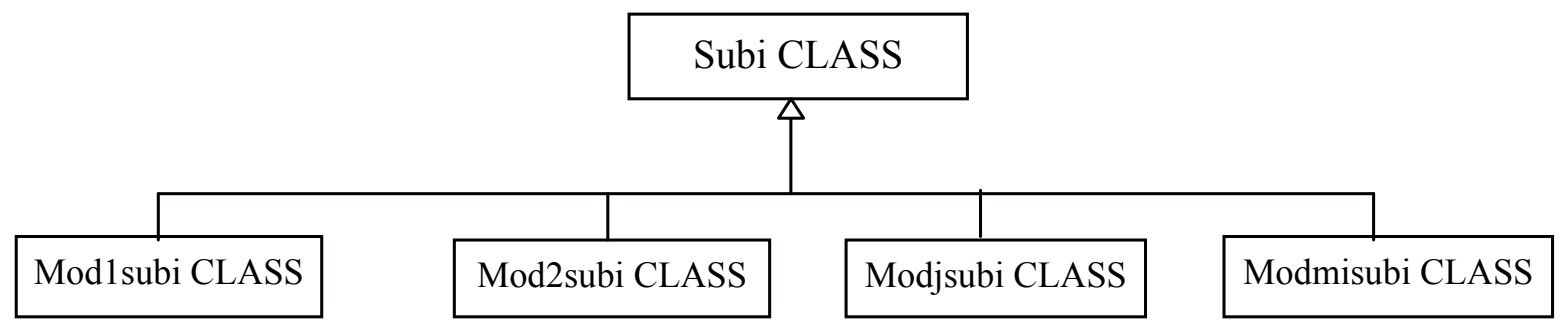

Fig. (2): Class diagrams

//System class

public class system implements requirement_documments

\{

//subi is the class of subsystem I, msubi is object from this class

private sub1 msub1;

private sub2 msub2;

private subi msubi;

- .

private subn msubn;

\}

//Object of the system class can be created by the constructor as follows

//class constructor

System (sub1 msub1, sub2 msub2, ...

Subn msubn) $\{\quad\}$

//methods of system class \{\}$\}$
//Subsystem class

public class sub1 implements csub1\{

$/ /$ misubj is the class of module $i$ in subsystem $\mathbf{j}$, mimsubj is object from this class.

private $\mathrm{m} 1 \mathrm{sub} 1 \mathrm{~m} 1 \mathrm{msub} 1$;

private $\mathrm{m} 2 \mathrm{sub} 1 \mathrm{~m} 2 \mathrm{msub} 1$;

private misub1 mimsub1;

private mnsub1 mnmsub1;

//Object of the subsystem class can be created by the constructor as follows //class constructor

Sub1(m1sub1 m1msub1, m2sub1 m2msub1,... mnsub1 mnmsub1)\{ \}

$/ / \operatorname{methods}$ of $\operatorname{sub1}\{\}\}$ 
An Object-Oriented Software Design Tool Using Automated Hoq And Ahp For Tracing And Prioritizing System Requirements.

Attia and Soliman

\section{TYPES OF MATRICES}

\subsection{The Q-Hoq Matrix (R2/S2/M2)}

The structure of the Q-HoQ matrix is shown in Fig.(3).

The most important components of a QHoQ are:

- Requirements: They are identified from customer statements or are obtained from the previous phase.

- Importance: The importance column in the matrix accommodates a list of importance ratings (real values between 1 and 9) for the requirements entered. Importance ratings can be achieved using the Analytical Hierarchy Process (AHP) Technique (Figs.(4),(5)).

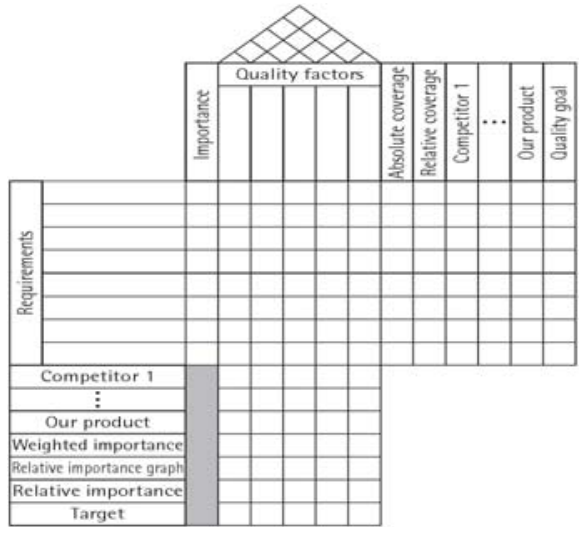

Fig.(3): The Q-HoQ Matrix

\begin{tabular}{|c|c|c|c|c|c|c|c|c|c|c|c|c|c|c|c|c|c|c|c|}
\hline $\begin{array}{l}\text { With re- } \\
\text { spect to } \\
" ~\end{array}$ & Impo & $\operatorname{tar}$ & & & $\mathbf{r} \mathbf{P}$ & & & & $\begin{array}{l}\text { ce) } \\
\text { not }\end{array}$ & of & or & le & ub & $\mathrm{Cr}$ & ter & ion & ov & & \\
\hline \multirow[t]{2}{*}{ Questions } & \multirow[t]{2}{*}{ Criteria } & 喑 & 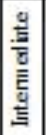 & 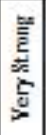 & 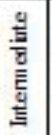 & 琶 & 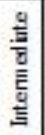 & 尊 & 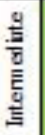 & $\overline{\bar{z}}$ & 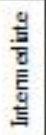 & $\stackrel{\text {. }}{\rightleftarrows}$ & 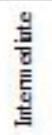 & 熟 & 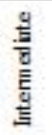 & 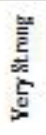 & 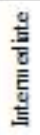 & 量 & \multirow[t]{2}{*}{ Criteria } \\
\hline & & 9 & 8 & 7 & 6 & 5 & 4 & 3 & 2 & 1 & 2 & 3 & 4 & 5 & 6 & 7 & 8 & 9 & \\
\hline & & & & & & & & & & & & & & & & & & & \\
\hline & & & & & & & & & & & & & & & & & & & \\
\hline
\end{tabular}

Fig. (4): A Questionnaire form for deciding on the importance index of the customer requirements

\begin{tabular}{|c|c|c|c|c|c|c|c|c|c|c|c|c|c|c|c|c|c|c|c|c|c|}
\hline \multicolumn{22}{|c|}{ Consistency Check - Eigenvector Method } \\
\hline & $\mathbf{A}$ & B & $\mathrm{C}$ & $\mathbf{D}$ & $\mathbf{E}$ & $\mathbf{F}$ & $\mathbf{G}$ & $\mathbf{H}$ & $\mathbf{I}$ & $\mathbf{J}$ & $\mathbf{K}$ & $\mathbf{L}$ & $\mathbf{M}$ & $\mathbf{N}$ & $\mathbf{O}$ & $\mathbf{P}$ & $\mathbf{Q}$ & $\mathbf{R}$ & $\mathrm{S}$ & $\mathrm{T}$ & \\
\hline & & $\bar{z}$ & $\underset{\mathbb{Z}}{\tilde{y}}$ & $\overline{\mathrm{A}}$ & تُّت & 先 & 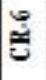 & 胥 & $\bar{z}$ & $\underset{\tilde{z}}{\tilde{z}}$ & 总 & 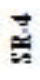 & $\underset{z}{*}$ & 莡 & 点 & $\underset{\sim}{\mathscr{z}}$ & ڤ્સિ & Score & Product & Ratio & \\
\hline 1 & CR-1 & 1 & & & & & & & 1 & 0 & 0 & 0 & 0 & 0 & 0 & 0 & 0 & 0.1111 & \#VALUE! & \#VALUE! & \\
\hline 2 & CR-2 & & 1 & & & & & & 0 & 1 & 0 & 0 & 0 & 0 & 0 & 0 & 0 & 0.1111 & \#VALUE! & \#VALUE! & \\
\hline 3 & CR-3 & & & 1 & & & & & 0 & 0 & 1 & 0 & 0 & 0 & 0 & 0 & 0 & 0.1111 & \#VALUE! & \#VALUE! & \\
\hline 4 & CR-4 & & & & 1 & & & & 0 & 0 & 0 & 1 & 0 & 0 & 0 & 0 & 0 & 0.1111 & \#VALUE! & \#VALUE! & \\
\hline 5 & CR-5 & & & & & 1 & & & 0 & 0 & 0 & 0 & 1 & 0 & 0 & 0 & 0 & 0.1111 & \#VALUE! & \#VALUE! & \\
\hline 6 & CR-6 & & & & & & 1 & & 0 & 0 & 0 & 0 & 0 & 1 & 0 & 0 & 0 & 0.1111 & \#VALUE! & \#VALUE! & \\
\hline 7 & CR-7 & & & & & & & 1 & 0 & 0 & 0 & 0 & 0 & 0 & 1 & 0 & 0 & 0.1111 & \#VALUE! & \#VALUE! & \\
\hline & & & & & & & & & 1 & 1 & 1 & 1 & 1 & 1 & 1 & 1 & 1 & 1 & CI & \#VALUE! & \\
\hline & & & & & & & & & & & & & & & & & & & CI/RI & \#VALUE! & \\
\hline
\end{tabular}

Fig. (5): Analytical hierarchy process for prioritizing customer requirements 
- Quality factors: The quality factors columns in the matrix accommodate a list of quality factors that contribute to the satisfaction of the requirements. Quality factors specify the desired quality attributes that need to be considered during the development of a particular software product, such as reliability, understandability, and so on.

- Correlation: The degree of impact of a quality factor on the satisfaction of a requirement is entered in a correlation matrix cell (the intersection of the quality factor and the requirement). Seven levels of impact are used to fill these cells. The fuzzy set is used to implement this correlation (Fig. (6)). Most researchers use special fuzzy numbers, such as triangular fuzzy numbers, trapezoidal fuzzy numbers, and R-L fuzzy numbers, to satisfy the need of modeling fuzzy problems. For simplicity, the most commonly used trapezoidal fuzzy numbers are used for necessary illustrations in this paper (Fig. (7)). The proposed fuzzy QFD model provides the ability for changing the level of linguistic certainty for the problem by altering the proposed linguistic certainty index. That is, selecting different spreads of fuzzy numbers will reveal different levels of linguistic certainty (Fig. (8)). A fuzzy number with a wider spread possesses a more ambiguous decision-making condition where the design team is uncertain with the evaluation. Conversely, a fuzzy number with a shorter spread represents a more clear and confident decision-making environment.

$$
\mu_{\tilde{A}}(x)= \begin{cases}l(x) & \text { for } x \in(\alpha, \beta) \\ 1 & \text { for } x \in[\beta, \gamma] \\ r(x) & \text { for } x \in(\gamma, \delta) \\ 0 & \text { otherwise }\end{cases}
$$

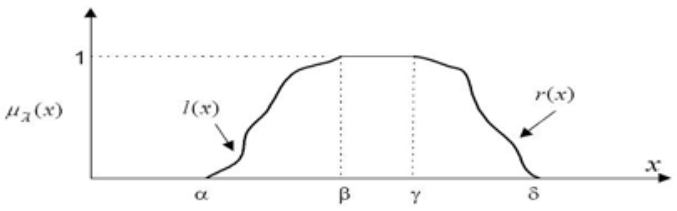

Fig. (6): A typical graph of a fuzzy number described by the equation above

The membership function of a trapezoidal fuzzy number will be:

$$
\mu_{i}(x)=\left\{\begin{array}{lll}
(x-\alpha) /(\beta-\alpha) & \text { for } & x \in[\alpha, \beta] \\
1 & \text { for } & x \in[\beta, \gamma] \\
(x-\delta) /(\gamma-\delta) & \text { for } & x \in[\gamma, \delta] \\
0 & \text { for } & x \in(-\infty, \alpha) \text { and } x \in(\delta, \infty)
\end{array}\right.
$$

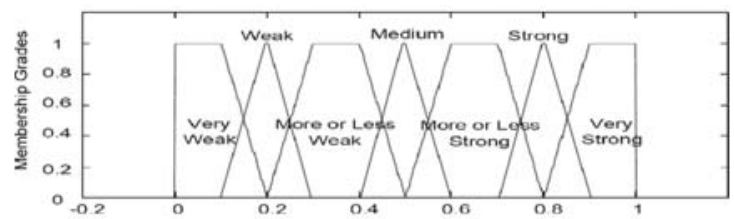

Fig. (7): Linguistic terms for correlation
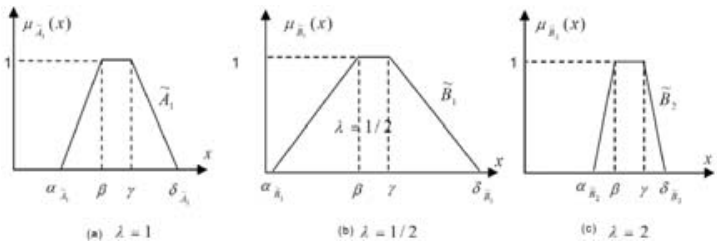

Fig. (8): Different fuzzy numbers revealing different linguistic certainty levels

- Absolute coverage: The absolute coverage of a requirement is examined against its corresponding quality factors in the matrix. For each requirement $\mathrm{X}$, across all quality factors, $\mathrm{Y}$ is calculated as:

$$
\begin{array}{r}
\text { ABS_Coverage }\left(X_{i}\right)=\sum_{k=1}^{\#_{2} \text { Quality Factors }} \text { Correlation }\left(X_{i}, Y_{k}\right) \\
\text { (Equation 1) }
\end{array}
$$

- Relative coverage: The relative coverage of a requirement is examined against those of all requirements. For each requirement $\mathrm{X}$, the relative coverage is calculated as: 
An Object-Oriented Software Design Tool Using Automated Hoq And Ahp For Tracing And Prioritizing System Requirements.

Attia and Soliman

$R E L \_$Coverage $\left(X_{i}\right)=\frac{\text { \#BS_Coverage }\left(X_{i}\right)}{\sum_{k=1} \operatorname{Aequirements}} \times 10$
(Equation 2)

The relative coverage ensures that a highpriority customer requirement receives coverage proportional to its priority.

- Weighted and relative importance: For each quality factor $\mathrm{X}$, across all requirements $\mathrm{Y}$, the weighted importance value can be calculated from the importance values of the requirements and the correlation values between this quality factor and all requirements as follows:

Weighted_IMP $\left(X_{i}\right)=\sum_{k=1}^{\# \text { Requirements }}$ Correlation $\left.\left(Y_{k}, X_{i}\right) \times I M P\left(Y_{k}\right)\right)$

(Equation 3)

With all the weighted importance values calculated, the relative importance value of a quality factor $\mathrm{X}$ can be obtained as follows:

$$
\begin{gathered}
R E L \_I M P\left(X_{i}\right)=\frac{\text { Weighted_IMP }\left(X_{i}\right)}{\sum_{k=1} \text { Wuality_Factors }} \times 10 \\
\text { (Equhted_IMP }\left(X_{k}\right)
\end{gathered}
$$

- Target: The development targets are set for one's product.

- Roof: The roof contains the tradeoffs between the quality elements. A plus sign (+) is used to indicate a positive relation and a minus sign (-) to indicate a negative relation. If improving the satisfaction of one quality factor will harm another, a negative relation exists between the two.

For instance, if the fault tolerance requires more safety checking and recovering calculation, it will very likely sacrifice the efficiency of the system. Thus, fault tolerance and efficiency are negatively related. Conversely, if one quality factor improves another, there is a positive relation.

\subsection{The F-HoQ Matrix (R1/S1/M1)}

The structure of the F-HoQ matrix is shown in Fig. (9).

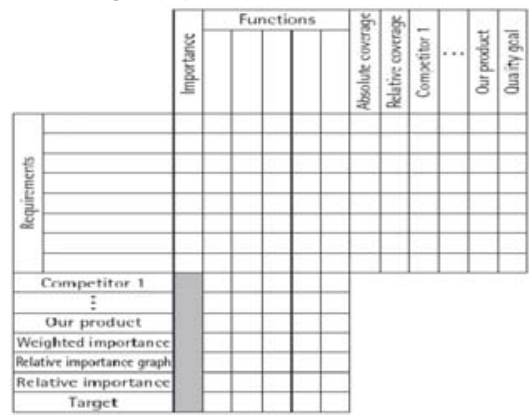

Fig. (9): The F-HoQ matrix

It differs from the Q-HoQ by not having the roof, because the functions are implementation independent. Hence, negative correlations among them are rare. In addition, the F-HoQ deploys requirements to functions instead of quality factors. The calculations of the absolute and relative coverages for the requirements and the weighted and relative importance values for the functions are similar to Equations 1 to 4 used in the Q-HoQ.

\subsection{Design Point Analysis Matrix (R3/S3)}

The structure of the design point analysis matrix is shown in Fig. (10).

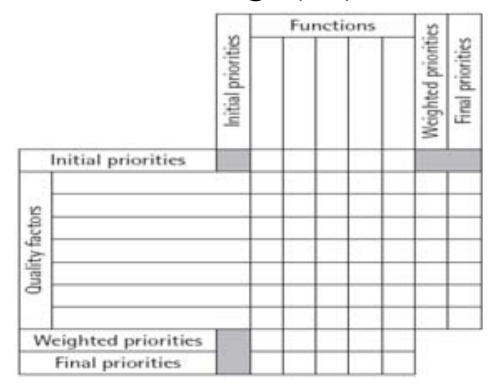

\section{Fig.(10): The design point analysis matrix}

It is used to integrate functions and quality factors by examining their impacts on each other. The aim is to produce technical requirements for the next phase so that the original customer requirements are 
traced along the design of the system components. Following is a list of the components in the design point analysis matrix:

\section{- Quality factors and functions:} These are obtained from the Q-HoQ and F-HoQ matrices.

- Initial priorities: These are obtained from the relative importance values calculated in the Q-HoQ and F-HoQ matrices.

- Correlation: The degree of importance of a quality factor on a function is entered in a correlation matrix cell (the intersection of the quality factor and the function) using crisp values. Three levels of impact are used to fill these cells (as shown in Table (1)).

Table (1): Correlation between requirements/quality factors and functions

\begin{tabular}{|c|c|c|}
\hline (O) & Strong & $\mathbf{9}$ \\
\hline$\bigcirc$ & Medium & $\mathbf{3}$ \\
\hline$\nabla$ & Weak & $\mathbf{1}$ \\
\hline
\end{tabular}

- Weighted priorities: For each quality factor $\mathrm{X}$ and each function $\mathrm{Y}$, the weighted priority can be calculated from the initial priority values and the correlation values as follows:

Weighted_P $\left(X_{i}\right)=\sum_{k=1}^{\# \text { functions }}\left(\right.$ Init_P $P\left(X_{i}\right) \times$ Correlation $\left(X_{p} Y_{k}\right) \times$ Init_P $\left(Y_{k}\right)$

(Equation 5)

Weighted_P $\left(Y_{i}\right)=\sum_{k=1}^{\text {\#Quality Factors }}\left(\right.$ Init_P $\left(Y_{i}\right) \times$ Correlation $\left(Y_{i} X_{k}\right) \times$ Init_P $\left(X_{k}\right)$

(Equation 6)

- Final priorities: For each quality factor $\mathrm{X}$ and each function $\mathrm{Y}$

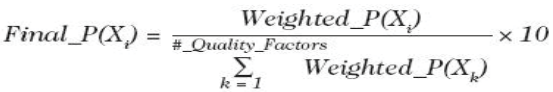

$$
\begin{aligned}
& \text { Final_P(Y, }=\frac{\text { Weighted_P }\left(Y_{i}\right)}{\#_{k} \sum_{k=1}^{\text {Eunctions }} \text { Weighted_P(Yation 7) }} \times 10
\end{aligned}
$$

These final priorities are calculated for traceability purpose. They reflect the level of satisfaction of the original set of customer requirements.

\section{ANAPPLICATION EXAMPLE}

The design of a remote sensing microsatellite system, through which customers requirements are deployed through the design process, was chosen as an example to illustrate the QFD methodology for objectoriented software development. A number of requirements were elicited. From these requirements, the system design starts with a number of major system functionalities as well as system constraints. Figs. (11) - (13) were constructed for the requirements elicitation phase. When it moves to the subsystem design phase, the system functionalities and constraints become the subsystem requirements from which the subsystem constraints and functionalities are listed. Figs. (14) - (16) were constructed for this phase. Finally; the subsystem constraints and functionalities are used to develop module-level functionalities and constraints. Figs. (17) and (18) were developed for the module design phase. Following is an explanation of the HoQs constructed in the three design phases.

\subsection{Phase 1: Customer Require- ments System Requirements}

The Q-HoQ shown in Fig. (11) and the FHoQ shown in Fig. (12) were developed to deploy the system- level requirements to the system-level product functions and quality factors, respectively. In both figures, the requirements are listed in rows. Fig. (13) is the design point analysis matrix used to analyze the correlation between the quality factors and the functionalities and to integrate them.

Table (2) shows requirements, functions and constraints which have been investigated by the customers and design team at different phases of design of the microsatellite. 
An Object-Oriented Software Design Tool Using Automated Hoq And Ahp For Tracing And Prioritizing System Requirements.

Table (2): Requirements, functions and constraints at different phases of design of the microsatellite

\begin{tabular}{|c|c|c|c|c|c|c|c|c|c|c|}
\hline & \multicolumn{2}{|c|}{$\begin{array}{l}\text { Customer Require- } \\
\text { ments }\end{array}$} & \multicolumn{2}{|c|}{ System Requirements } & \multicolumn{3}{|c|}{ Subsystem Functions } & \multicolumn{3}{|c|}{ Module Functions } \\
\hline \multirow{30}{*}{ 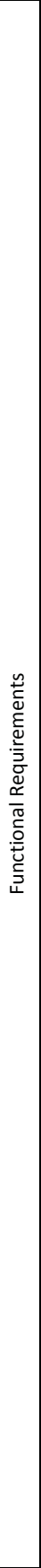 } & CR1 & $\begin{array}{l}\text { Image Quality } \\
(\mathrm{S} / \mathrm{N})\end{array}$ & SR1 & Orbit altitude & SF1 & $\overline{\mathrm{MBEI}}$ & $\begin{array}{c}\text { Acquire reflected Earth radiation } \\
\text { energy \& Transform it to electric } \\
\text { signals }\end{array}$ & MF1 & $\overline{\mathrm{MBEI}}$ & Optical System \\
\hline & CR2 & Resolution & SR2 & Orbit inclination & SF2 & & Amplify \& Transform to digital code & MF2 & & $\mathrm{CCD}$ \\
\hline & CR3 & $\begin{array}{c}\text { Location Accura } \\
\text { cy }\end{array}$ & SR3 & $\begin{array}{l}\text { Scanner aper- } \\
\text { ture size }\end{array}$ & SF3 & & $\begin{array}{l}\text { Digital Processing \& adding } \\
\text { service information }\end{array}$ & MF3 & & SPE \\
\hline & CR4 & Coverage & SR4 & $\begin{array}{c}\text { Scanner field of } \\
\text { view }\end{array}$ & SF4 & PLCDHS & $\begin{array}{l}\text { Receive and store in MMU, image } \\
\text { info (MBEI) and commands \& } \\
\text { annotation info (PCDHS) }\end{array}$ & MF4 & PLCDHS & $\overline{C D A U}$ \\
\hline & CR5 & Imaging Capacit & SR5 & Scanner MTF & SF5 & & $\begin{array}{c}\text { Form \& transfer output frames } \\
\text { information to X-band }\end{array}$ & MF5 & & MMU \\
\hline & CR6 & Responsiveness & SR6 & MMU size & SF6 & \multirow[t]{3}{*}{ CSS } & $\begin{array}{l}\text { Receive commands \& data files } \\
\text { from GCS }\end{array}$ & MF6 & \multirow[t]{5}{*}{ CSS } & S-band Tx \\
\hline & CR7 & Lifetime & SR7 & $\begin{array}{l}\text { OB Data } \\
\text { processing }\end{array}$ & SF7 & & $\begin{array}{c}\text { Transmit acknowledgement, TM, } \\
\text { and data files to GCS }\end{array}$ & MF7 & & S-band Rx \\
\hline & & & SR8 & Average \& peak power & SF8 & & Transmit image video data to GDRS & MF8 & & S-band AFD \\
\hline & & & SR9 & Data rates & SF9 & GPS & $\begin{array}{c}\text { Receive, navigating signals from } \\
\text { GPS constellation \& Measure } \\
\text { current satellite navigation } \\
\text { parameters }\end{array}$ & MF9 & & X-band Tx \\
\hline & & & SR10 & $\mathrm{S} / \mathrm{N}$ ratios & SF10 & & $\begin{array}{c}\text { Send current motion parameters, } \\
\text { GPS second mark, GPS TMI to } \\
\text { PCDHS }\end{array}$ & MF10 & & X-band AFD \\
\hline & & & SR11 & Stabilization & SF11 & \multirow[t]{5}{*}{ PCDHS } & $\begin{array}{l}\text { Receive, protect, switch and } \\
\text { distribute power }\end{array}$ & MF11 & \multirow[t]{2}{*}{ GPS } & GPS-NSR \\
\hline & & & SR12 & $\begin{array}{c}\text { Pointing accura- } \\
\text { cy }\end{array}$ & SF12 & & $\begin{array}{l}\text { Control work of PCDHS \& } \\
\text { PLCDHS }\end{array}$ & MF12 & & GPS-AFD \\
\hline & & & SR13 & Slew rate & SF13 & & $\begin{array}{l}\text { TMI collection, processing \& } \\
\text { transfer }\end{array}$ & MF13 & \multirow[t]{5}{*}{ PCDHS } & PCDHS-CPDB \\
\hline & & & SR14 & Max roll angle & SF14 & & OTS handling & MF14 & & $\mathrm{OBC}$ \\
\hline & & & SR15 & $\begin{array}{l}\text { Transmitter } \\
\text { power }\end{array}$ & SF15 & & $\begin{array}{l}\text { Form annotation information for } \\
\text { PLCDHS }\end{array}$ & MF15 & & PCDHS-CCU \\
\hline & & & SR16 & $\begin{array}{l}\mathrm{G} / \mathrm{T}, \mathrm{Rx} \text { sensitivi- } \\
\text { ty }\end{array}$ & SF16 & \multirow[t]{3}{*}{ ADCS } & attitude determination & MF16 & & PCDHS-CM \\
\hline & & & SR17 & Staffing & SF17 & & $\begin{array}{l}\text { pointing accuracy at normal and } \\
\text { standby modes }\end{array}$ & MF17 & & $\begin{array}{l}\text { PCDHS-TM } \\
\text { Module }\end{array}$ \\
\hline & & & & & SF18 & & Realization of program rotations & MF18 & \multirow[t]{2}{*}{ ADCS } & ADCS Sensors \\
\hline & & & & & SF19 & PSS & $\begin{array}{l}\text { Generate, store, provide and } \\
\text { control power }\end{array}$ & MF19 & & ADCS Actuators \\
\hline & & & & & SF20 & TSS & $\begin{array}{c}\text { Temperature maintenance for OB } \\
\text { equipment }\end{array}$ & MF20 & \multirow[t]{3}{*}{ PSS } & Solar Arrays \\
\hline & & & & & SF21 & Structure & $\begin{array}{l}\text { Provide required relative attitude } \\
\text { of subsystems \& units of satellite }\end{array}$ & MF21 & & Battery \\
\hline & & & & & SF22 & \multirow[t]{5}{*}{ GCS } & Generate \& transmit commands & MF22 & & PCU \\
\hline & & & & & SF23 & & $\begin{array}{l}\text { Receive \& process acknowledg- } \\
\text { ment and telemetry }\end{array}$ & MF23 & \multirow[t]{6}{*}{ GCS } & GCS-TX \\
\hline & & & & & SF24 & & $\begin{array}{l}\text { Process measured satellite naviga- } \\
\text { tion parameters }\end{array}$ & MF24 & & GCS-Rx \\
\hline & & & & & SF25 & & $\begin{array}{c}\text { Forecast satellite motion parame- } \\
\text { ters }\end{array}$ & MF25 & & FCC-PPS \\
\hline & & & & & SF26 & & $\begin{array}{l}\text { Measure mismatch between OB } \\
\text { and ground time scales }\end{array}$ & MF26 & & FCC-CSS \\
\hline & & & & & SF27 & GDRS & $\begin{array}{l}\text { Receive, demodulate, decode X- } \\
\text { band radio signal }\end{array}$ & MF27 & & FCC-Navigation \\
\hline & & & & & SF28 & & $\begin{array}{c}\text { Preliminary processing of video } \\
\text { information }\end{array}$ & MF28 & & $\begin{array}{c}\text { FCC-TM } \\
\text { Processing }\end{array}$ \\
\hline & & & & & SF29 & & Information archiving & MF29 & \multirow[t]{2}{*}{ GDRS } & GDRS-Rx \\
\hline & & & & & & & & MF30 & & GDRS Processing \\
\hline \multirow{4}{*}{ 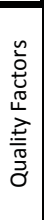 } & & & QF1 & Availability & SC1 & & Subsystem Redundancy & MC1 & & $\begin{array}{l}\text { Cold \& hot Re- } \\
\text { dundancy }\end{array}$ \\
\hline & & & QF2 & Level of security & $\mathrm{SC} 2$ & & Subsystem Reliability & MC2 & & $(\mathrm{m} / \mathrm{n})$ majority voting \\
\hline & & & QF3 & $\begin{array}{c}\text { Operation } \\
\text { Effectiveness }\end{array}$ & $\mathrm{SC} 3$ & & Satellite Access Control & MC3 & & $\begin{array}{c}\text { S-band access } \\
\text { keys }\end{array}$ \\
\hline & & & & & SC4 & & $\begin{array}{l}\text { Parts, Materials and Processes } \\
\text { Program }\end{array}$ & MC4 & & Module Reliability \\
\hline
\end{tabular}


Vol.14, No. 1

Tables (3), and 4 shows how to calculate the importance index for customer requirements using the Analytical Hierarchy process and also a consistency check using the method of Eigen Vectors.

Table (3): A Questionnaire for estimating the preference of one customer requirement to another

\begin{tabular}{|c|c|c|c|c|c|c|c|c|c|c|c|c|c|c|c|c|c|c|c|}
\hline $\begin{array}{c}\text { With } \\
\text { respect to }\end{array}$ & Imp & anc & (or & Pre & fere & nce & of & ne & Sub & Crit & erio & ov & er a & noth & & & & & \\
\hline \multirow{2}{*}{ 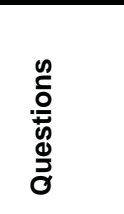 } & \multirow[t]{2}{*}{ Criteria } & 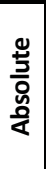 & 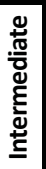 & 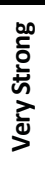 & 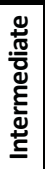 & 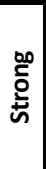 & 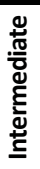 & $\sum_{3}^{\frac{5}{\pi}}$ & 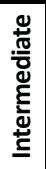 & 㞼 & 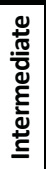 & 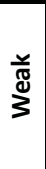 & 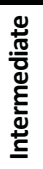 & 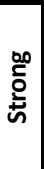 & 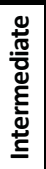 & 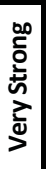 & 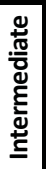 & 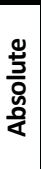 & \multirow[t]{2}{*}{ Criteria } \\
\hline & & 9 & 8 & 7 & 6 & 5 & 4 & 3 & 2 & 1 & 2 & 3 & 4 & 5 & 6 & 7 & 8 & 9 & \\
\hline 1 & Image Quality (S/N) & & & & & & & & & & & & & & & $\mathrm{x}$ & & & Resolution \\
\hline 2 & Image Quality (S/N) & & & & & & & & & & & & & $\mathrm{x}$ & & & & & Location Accuracy \\
\hline 3 & Image Quality (S/N) & & & & & & & & $\mathbf{x}$ & & & & & & & & & & Coverage \\
\hline 4 & Image Quality (S/N) & & & & & & & $\mathrm{x}$ & & & & & & & & & & & Imaging Capacity \\
\hline 5 & Image Quality (S/N) & & & & $x$ & & & & & & & & & & & & & & Responsiveness \\
\hline 6 & Image Quality (S/N) & & & $\mathbf{x}$ & & & & & & & & & & & & & & & Lifetime \\
\hline 7 & Resolution & & & & & & & & $\mathrm{x}$ & & & & & & & & & & Location Accuracy \\
\hline 8 & Resolution & & & & & & & $\mathbf{x}$ & & & & & & & & & & & Coverage \\
\hline 9 & Resolution & & & & & & $\mathbf{x}$ & & & & & & & & & & & & Imaging Capacity \\
\hline 10 & Resolution & & & & & $\mathrm{x}$ & & & & & & & & & & & & & Responsiveness \\
\hline 11 & Resolution & & & & $x$ & & & & & & & & & & & & & & Lifetime \\
\hline 12 & Location Accuracy & & & & & & & $\mathrm{x}$ & & & & & & & & & & & Coverage \\
\hline 13 & Location Accuracy & & & & & & $x$ & & & & & & & & & & & & Imaging Capacity \\
\hline 14 & Location Accuracy & & & & & $\mathbf{x}$ & & & & & & & & & & & & & Responsiveness \\
\hline 15 & Location Accuracy & & & & $x$ & & & & & & & & & & & & & & Lifetime \\
\hline 16 & Coverage & & & & & & & & $\mathrm{x}$ & & & & & & & & & & Imaging Capacity \\
\hline 17 & Coverage & & & & & & & $x$ & & & & & & & & & & & Responsiveness \\
\hline 18 & Coverage & & & & & & $\mathbf{x}$ & & & & & & & & & & & & Lifetime \\
\hline 19 & Imaging Capacity & & & & & & & & $\mathbf{x}$ & & & & & & & & & & Responsiveness \\
\hline 20 & Imaging Capacity & & & & & & & $\mathrm{x}$ & & & & & & & & & & & Lifetime \\
\hline 21 & Responsiveness & & & & & & & & $\mathrm{x}$ & & & & & & & & & & Lifetime \\
\hline
\end{tabular}


An Object-Oriented Software Design Tool Using Automated Hoq And Ahp For Tracing And Prioritizing System Requirements.

Attia and Soliman

\section{Table (4): The AHP method for calculation of Customer Requirements} importance index

\begin{tabular}{|c|c|c|c|c|c|c|c|c|}
\hline & A & B & C & D & E & $\mathbf{F}$ & G & H \\
\hline & & 宅 & 气̃ & 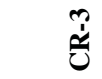 & 茪 & هُّ & پِّ & ثี \\
\hline 1 & CR-1 & 1 & $1 / 7$ & $1 / 5$ & 2 & 3 & 6 & 7 \\
\hline 2 & CR-2 & 7 & 1 & 2 & 3 & 4 & 5 & 6 \\
\hline 3 & CR-3 & 5 & $1 / 2$ & 1 & 3 & 4 & 5 & 6 \\
\hline 4 & CR-4 & $1 / 2$ & $1 / 3$ & $1 / 3$ & 1 & 2 & 3 & 4 \\
\hline 5 & CR-5 & $1 / 3$ & $1 / 4$ & $1 / 4$ & $1 / 2$ & 1 & 2 & 3 \\
\hline 6 & CR-6 & $1 / 6$ & $1 / 5$ & $1 / 5$ & $1 / 3$ & $1 / 2$ & 1 & 2 \\
\hline 7 & CR-7 & $1 / 7$ & $1 / 6$ & $1 / 6$ & $1 / 4$ & $1 / 3$ & $1 / 2$ & 1 \\
\hline
\end{tabular}

Consistency Check - Eigen value / Eigenvector Method

\begin{tabular}{|c|c|c|c|c|c|c|c|c|c|c|c|c|c|c|c|c|c|c|}
\hline & $\mathbf{A}$ & B & $\mathrm{C}$ & D & $\mathbf{E}$ & $\mathbf{F}$ & G & $\mathrm{H}$ & I & $\mathbf{J}$ & $\mathbf{K}$ & $\mathbf{L}$ & M & $\mathbf{N}$ & O & $\mathbf{P}$ & $\mathbf{Q}$ & $\mathbf{R}$ \\
\hline & & $\overrightarrow{\tilde{U}}$ & $\begin{array}{l}\tilde{\varkappa} \\
\tilde{U}\end{array}$ & 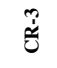 & 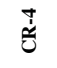 & 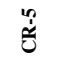 & 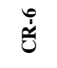 & $\hat{\tilde{U}}$ & ऊิ & 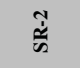 & ซึ & 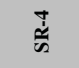 & 絖 & ๗ँ & ळै & Score & Product & Ratio \\
\hline 1 & CR-1 & 1.00 & 0.14 & 0.20 & 2.00 & 3.00 & 6.00 & 7.00 & \begin{tabular}{|l|}
0.0707 \\
\end{tabular} & 0.0551 & 0.0482 & 0.1983 & 0.2022 & 0.2667 & 0.2414 & 0.15466236 & 1.1682 & 7.5532 \\
\hline 2 & \begin{tabular}{|l|} 
CR-2 \\
\end{tabular} & 7.00 & 1.00 & 2.00 & 3.00 & 4.00 & 5.00 & 6.00 & \begin{tabular}{|l|}
0.4949 \\
\end{tabular} & 0.3857 & 0.4819 & 0.2975 & 0.2697 & 0.2222 & 0.2069 & $\begin{array}{l}0.33697921 \\
\end{array}$ & 2.9441 & 8.7368 \\
\hline 3 & CR-3 & 5.00 & 0.50 & 1.00 & 3.00 & 4.00 & 5.00 & 6.00 & 0.3535 & 0.1928 & 0.2410 & 0.2975 & 0.2697 & 0.2222 & 0.2069 & 0.25480558 & 2.2115 & 8.6792 \\
\hline 4 & CR-4 & 0.50 & 0.33 & 0.33 & 1.00 & 2.00 & 3.00 & 4.00 & 0.0354 & 0.1286 & 0.0803 & 0.0992 & 0.1348 & 0.1333 & 0.1379 & 0.10707179 & 0.7824 & 7.3071 \\
\hline 5 & CR-5 & 0.33 & 0.25 & 0.25 & 0.50 & 1.00 & 2.00 & 3.00 & \begin{tabular}{|l|}
0.0236 \\
\end{tabular} & 0.0964 & 0.0602 & 0.0496 & 0.0674 & 0.0889 & 0.1034 & 0.06993834 & 0.5073 & 7.2532 \\
\hline 6 & CR-6 & 0.17 & 0.20 & 0.20 & 0.33 & 0.50 & 1.00 & 2.00 & \begin{tabular}{|l|}
0.0118 \\
\end{tabular} & 0.0771 & 0.0482 & 0.0331 & 0.0337 & 0.0444 & 0.0690 & 0.04532685 & 0.3226 & 7.1161 \\
\hline \multirow[t]{3}{*}{7} & \begin{tabular}{|l|} 
CR-7 \\
\end{tabular} & 0.14 & 0.17 & 0.17 & 0.25 & 0.33 & 0.50 & 1.00 & \begin{tabular}{|l|}
0.0101 \\
\end{tabular} & 0.0643 & 0.0402 & 0.0248 & 0.0225 & 0.0222 & 0.0345 & $\mathbf{0 . 0 3 1 2 1 5 8 7}$ & 0.2247 & 7.1978 \\
\hline & & & & & & & & & 1 & 1 & 1 & 1 & 1 & 1 & 1 & 1 & CI & $\begin{array}{c}0.11532 \\
0\end{array}$ \\
\hline & & & & & & & & & & & & & & & & & $\mathbf{C I} / \mathbf{R I}$ & $\begin{array}{c}0.08736 \\
3\end{array}$ \\
\hline
\end{tabular}

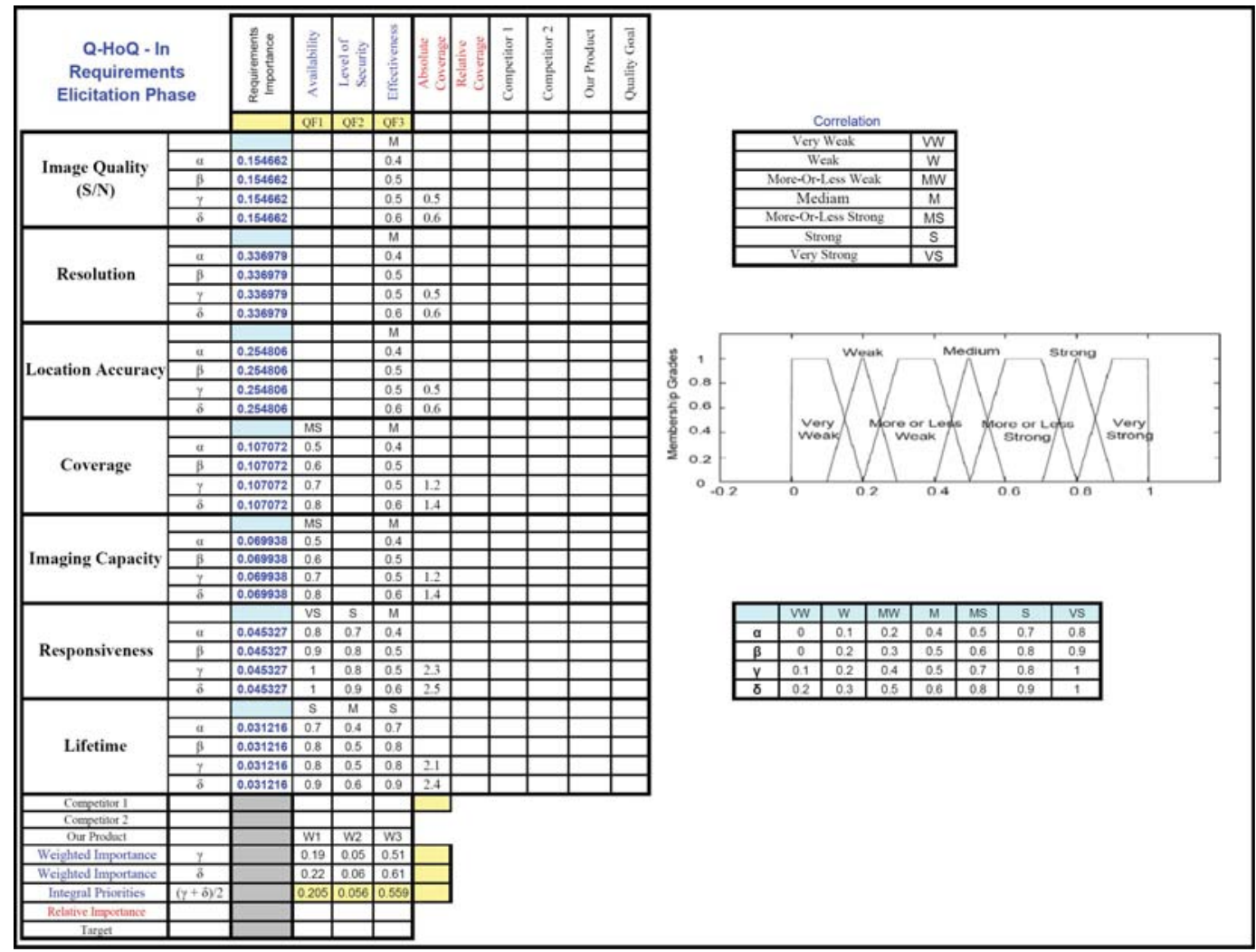

Fig. (11): Q-HoQ in requirements elicitation

phase - 
Vol.14, No. 1

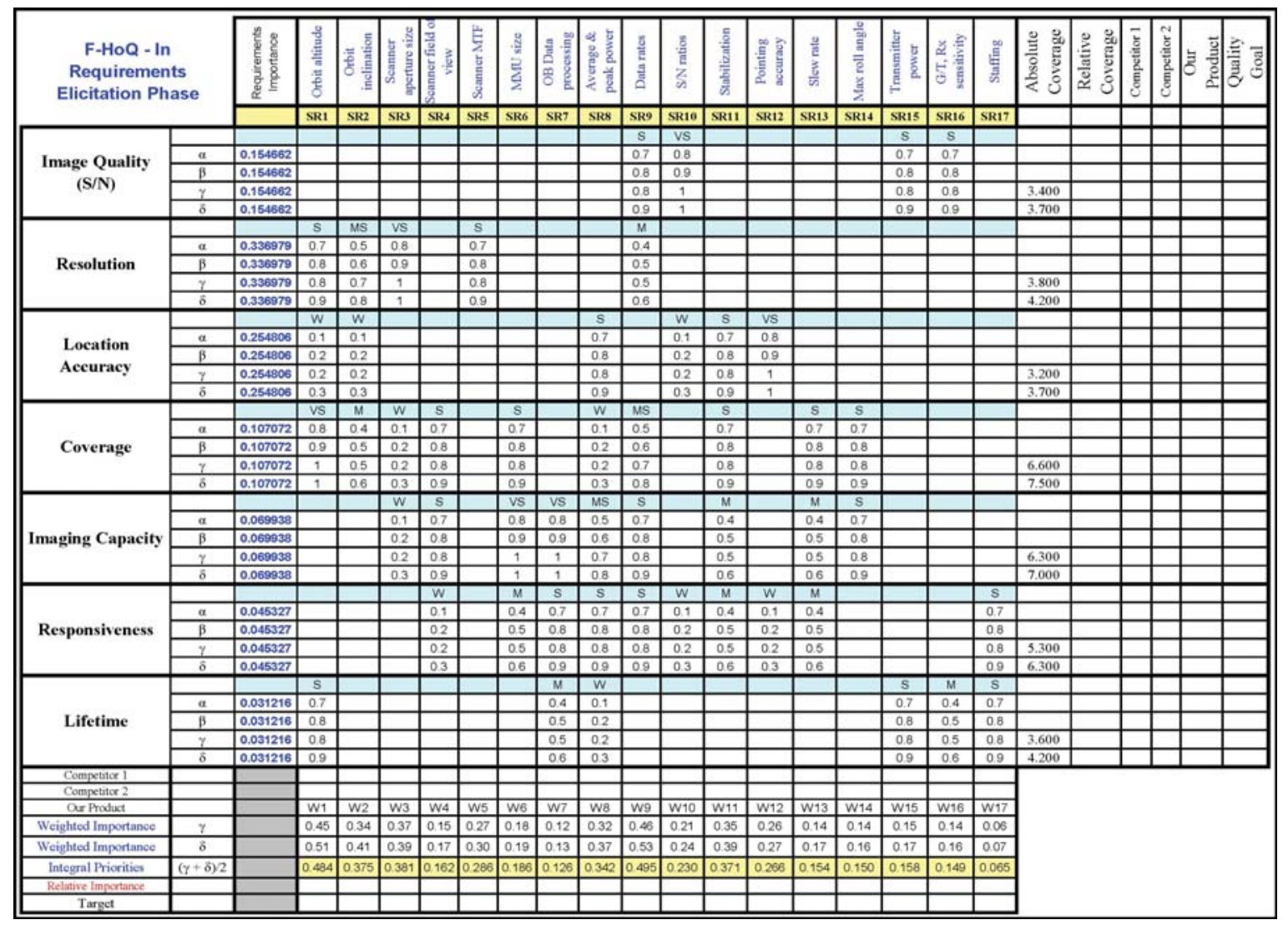

Fig. (12): F-HoQ in requirements elicitation phase

\begin{tabular}{|c|c|c|c|c|c|c|c|c|c|c|c|c|c|c|c|c|c|c|c|c|c|c|}
\hline \multirow{2}{*}{\multicolumn{3}{|c|}{$\begin{array}{c}\text { Design Point Analysis } \\
\text { Matrix - In } \\
\text { Requirements } \\
\text { Elicitation Phase }\end{array}$}} & 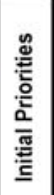 & 童 & 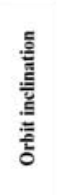 & 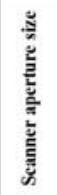 & 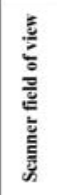 & 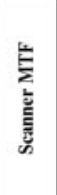 & $\frac{\stackrel{g}{L}}{\sum_{2}}$ & 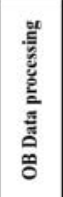 & 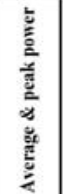 & 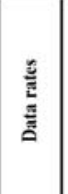 & 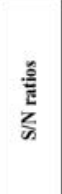 & 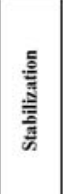 & 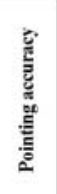 & $\begin{array}{l}\frac{\tilde{E}}{\text { है }} \\
\frac{\bar{z}}{\text { के }}\end{array}$ & 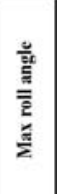 & | & 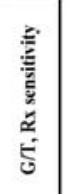 & 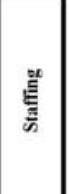 & 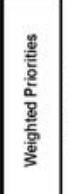 & \\
\hline & & & & SRI & $\mathrm{SR2}$ & $\mathrm{SR3}$ & \begin{tabular}{|l|l|} 
SR4 \\
\end{tabular} & $\mathrm{SRS}^{2}$ & SR6 & $\begin{array}{l}\mathrm{SR}^{2} \\
\end{array}$ & SRs & \begin{tabular}{|l} 
SRg \\
\end{tabular} & SR10 & SRII & SR12 & SR13 & SR14 & SRIS & SR16 & \begin{tabular}{|l} 
SR17 \\
\end{tabular} & & \\
\hline \multicolumn{3}{|c|}{ Initial Priorities } & & 0.484 & 0.375 & 0.381 & \begin{tabular}{|l|l|l|}
0.162 \\
\end{tabular} & 0.286 & 0.186 & $\begin{array}{ll}0.126 \\
\end{array}$ & 0.342 & \begin{tabular}{|l|l|l|}
0.495 \\
\end{tabular} & 0.230 & 0.371 & 0.266 & 0.154 & 0.150 & 0.158 & 0.149 & \begin{tabular}{|l|l|}
0.065 \\
\end{tabular} & & \\
\hline \multirow{5}{*}{ Availability } & & \multirow{5}{*}{ OFi } & 0.205 & & & & & & w & $\mathrm{s}$ & s & s & & w & & $w$ & w & MS & $M$ & $s$ & & \\
\hline & $a$ & & 0.205 & & & & & & 0.1 & 0.7 & 0.7 & 0.7 & & 0.1 & & 0.1 & 0.1 & 0.5 & 0.4 & 0.7 & & \\
\hline & $\frac{\beta}{\gamma}$ & & $\begin{array}{l}0.205 \\
0205\end{array}$ & & & & & & $\frac{0.2}{0.2}$ & 0.8 & $\begin{array}{l}0.8 \\
0.8\end{array}$ & $\frac{0.8}{0.8}$ & & 0.2 & & 0.2 & 0.2 & 0.6 & 0.5 & 0.8 & & \\
\hline & $\bar{s}$ & & 0205 & & & & & & 0.3 & 0.9 & 0.9 & 0.9 & & 0.2 & & $\frac{0.2}{0.3}$ & \begin{tabular}{l|l}
0.2 \\
0.3
\end{tabular} & $\frac{0.7}{0.8}$ & $\begin{array}{l}0.5 \\
0.6\end{array}$ & 0.8 & \begin{tabular}{|l|}
028000 \\
\end{tabular} & \\
\hline & $(y+\bar{\delta}) 2$ & & & & & & & & & & & & & & & & & & & & \begin{tabular}{|l|l|}
0.2643 \\
\end{tabular} & \\
\hline \multirow{6}{*}{$\begin{array}{l}\text { Level of } \\
\text { Security }\end{array}$} & & \multirow{5}{*}{$\mathrm{QF} / 2$} & 0.066 & w & w & & & & & w & w & $M$ & & & & & & MS & $M$ & vs & & \\
\hline & $a$ & & 0.056 & 0.1 & 0.1 & & & & & 0.1 & 0.1 & 0.4 & & & & & & 0.5 & 0.4 & 0.8 & & \\
\hline & $\beta$ & & 0.056 & 0.2 & 0.2 & & & & & 0.2 & 0.2 & 0.5 & & & & & & 0.6 & 0.5 & 0.9 & & \\
\hline & $\gamma$ & & 0.056 & 0.2 & 0.2 & & & & & 0.2 & 0.2 & 0.5 & & & & & & 0.7 & 0.5 & 1 & \begin{tabular}{|l|}
0.0427 \\
\end{tabular} & \\
\hline & ô & & 0.056 & 0.3 & 0.3 & & & & & 0.3 & 0.3 & 0.6 & & & & & & 0.8 & 0.6 & 1 & \begin{tabular}{|l|}
0.0546 \\
\end{tabular} & \\
\hline & $(y+6) 2$ & & 0.559 & & & $\bar{M}$ & $\bar{M}$ & MS & $M$ & $\bar{M}$ & $\bar{M}$ & MS & MS & & w & & & $M$ & $M$ & & & \\
\hline \multirow{4}{*}{ Effectiveness } & $a$ & \multirow{4}{*}{ OF3 } & 0.559 & & & 0.4 & 0.4 & 0.5 & 0.4 & 0.4 & 0.4 & 0.5 & 0.5 & & 0.1 & & & 0.4 & 0.4 & & & \\
\hline & B & & 0.559 & & & 0.5 & 0.5 & 0.6 & 0.5 & 0.5 & 0.5 & 0.6 & 0.6 & & 0.2 & & & 0.5 & 0.5 & & & \\
\hline & & & 0559 & & & 0.5 & 0.5 & 0.7 & 0.5 & 0.5 & 0.5 & 0.7 & 0.7 & & 0.2 & & & 0.5 & 0.5 & & \begin{tabular}{|l|l|}
0.8456 \\
\end{tabular} & \\
\hline & $\frac{\hat{\sigma}}{(y+\hat{b}) 2}$ & & 0.559) & & & 0.6 & 0.6 & 0.8 & 0.6 & 0.6 & 0.6 & 0.8 & 0.8 & & 0.3 & & & 0.6 & 0.6 & & \begin{tabular}{|l|}
1.0011 \\
\end{tabular} & \\
\hline $\begin{array}{c}\text { Weighted } \\
\text { Importance }\end{array}$ & $\gamma$ & & & 0.005 & 0.004 & 0.107 & 0.045 & 0.112 & 0.060 & 0.057 & 0.156 & 0.289 & 0.090 & 0.015 & 0.030 & 0.006 & 0.006 & 0.073 & 0.061 & 0.0143 & & \\
\hline $\begin{array}{c}\text { Weighted } \\
\text { Importance } \\
\end{array}$ & 6 & & & 0.008 & 0.006 & 0.128 & 0.054 & 0.128 & 0.074 & 0.067 & 0.184 & 0.329 & 0.103 & 0.023 & 0.045 & 0.009 & 0.009 & 0.086 & 0.073 & 0.0156 & & \\
\hline $\begin{array}{l}\text { Integral } \\
\text { Priorities }\end{array}$ & $(\gamma+\tilde{\delta}) / 2$ & & & 0.0068 & 0.0053 & 0.1172 & 0.0497 & 0.1201 & 0.0667 & 0.0623 & 0.1606 & 0.3091 & 0.0963 & 0.0190 & 0.0372 & 0.0079 & 0.0077 & 0.0795 & 0.0670 & 0.0150 & & \\
\hline \multicolumn{3}{|c|}{ Final Prioutities } & & & & & & & & & & & & & & & & & & & & \\
\hline
\end{tabular}

Fig. (13): DPAM in requirements elicitation phase 
An Object-Oriented Software Design Tool Using Automated Hoq And Ahp For Tracing And Prioritizing System Requirements.

Attia and Soliman

\subsection{Phase 2: System Requirements}

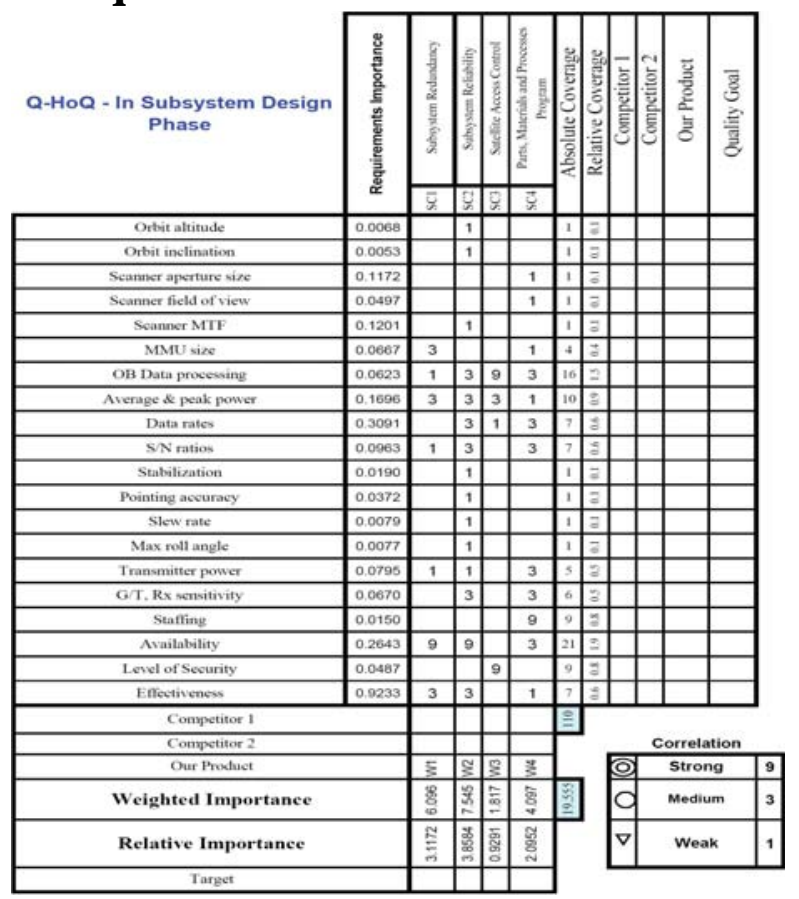

Fig. (14): Q-HoQ in subsystem design phase

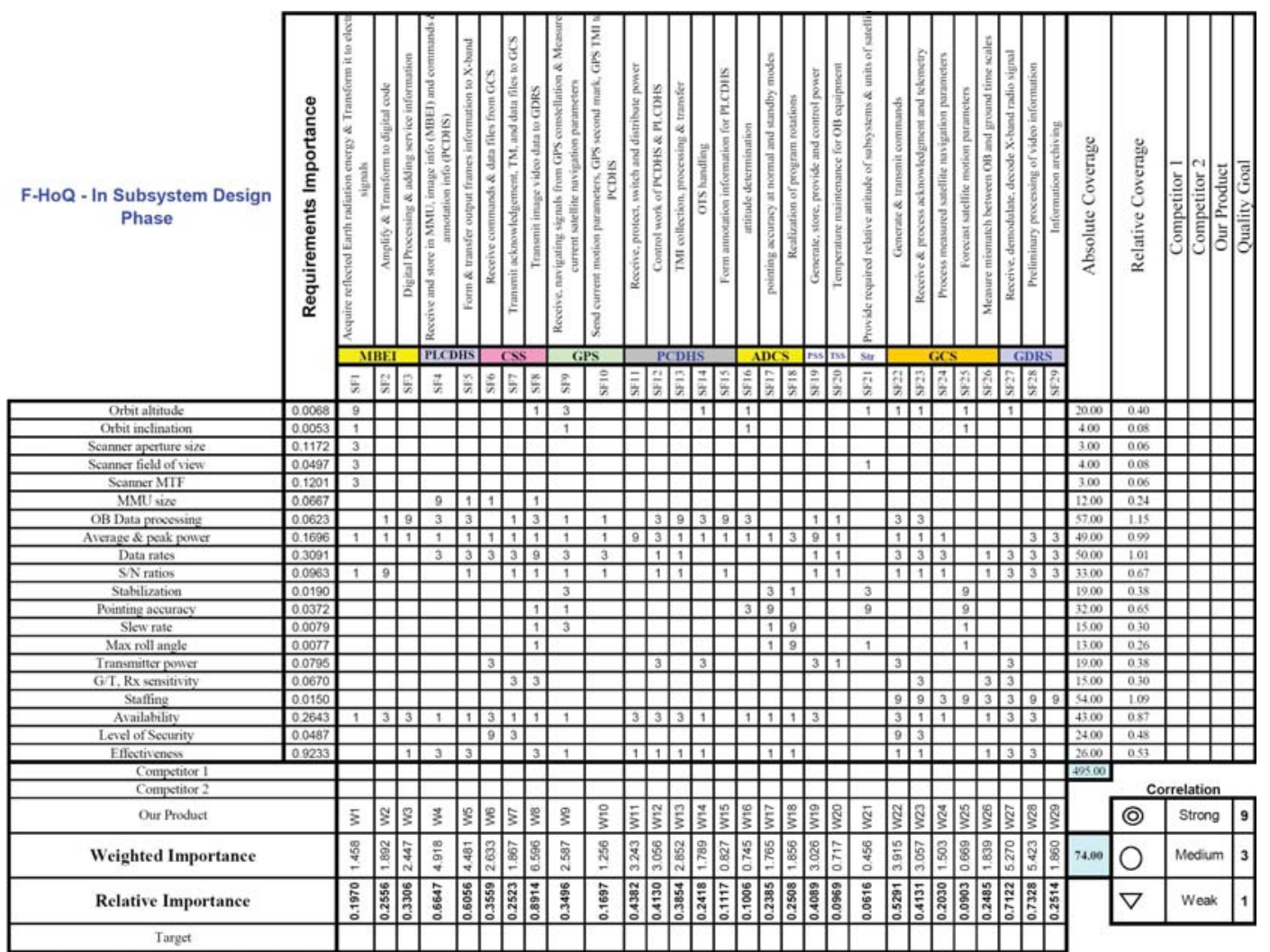

Fig. (15): F-HoQ in subsystem design phase 
Vol.14, No. 1

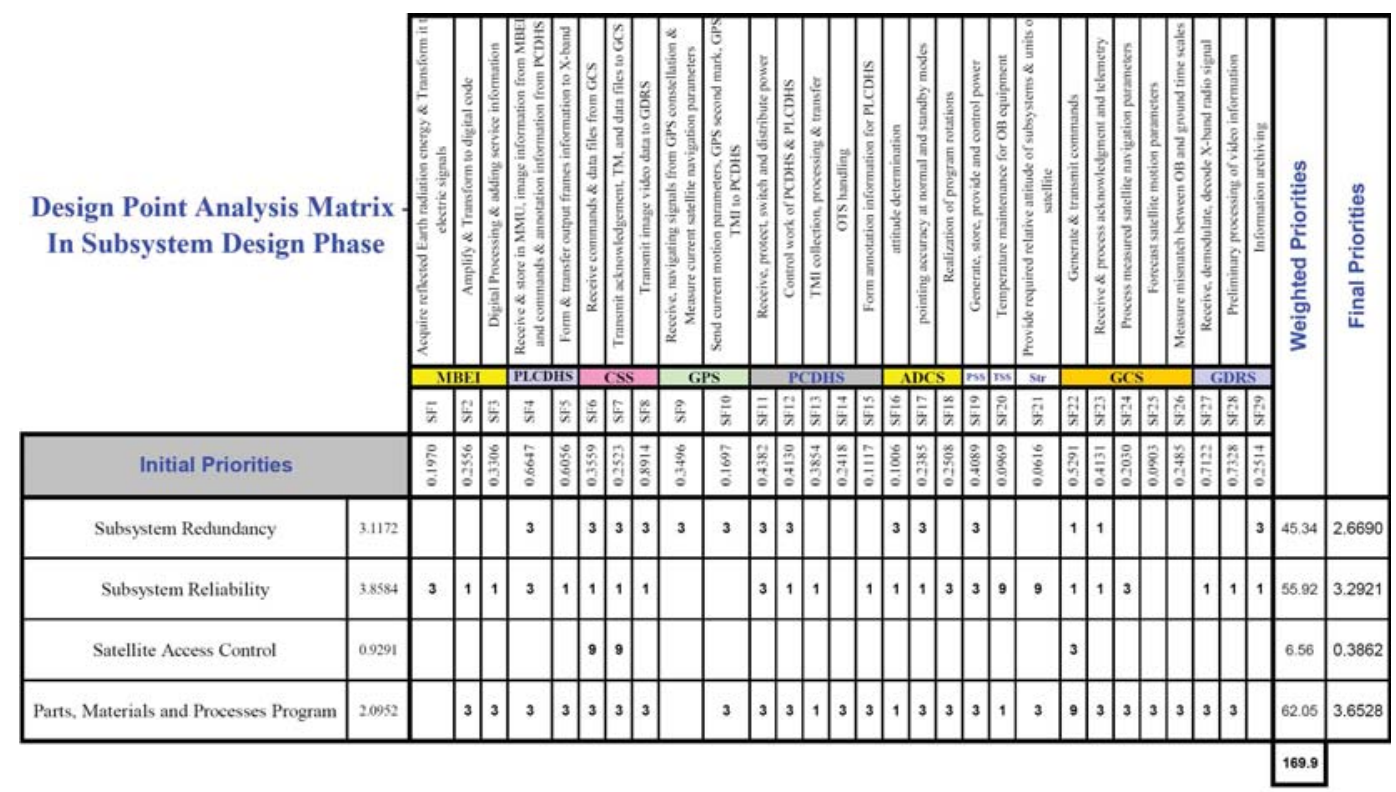

\begin{tabular}{|c|c|c|c|c|c|c|c|c|c|c|c|c|c|c|c|c|c|c|c|c|c|c|c|c|c|c|c|c|c|}
\hline Weighted Priorities & స్ & \begin{tabular}{|l|l|}
\multirow{2}{*}{} \\
$\mathrm{N}$
\end{tabular} & & $\begin{array}{l}8 \\
\vdots \\
0\end{array}$ & $\begin{array}{l}\square \\
0 \\
\end{array}$ & Б5 & \begin{tabular}{l}
\multirow{2}{*}{} \\
\hdashline \\
\end{tabular} & 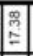 & స్ల & $\stackrel{\bullet}{\stackrel{8}{*}}$ & 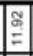 & $\begin{array}{l}8 \\
\infty \\
\end{array}$ & तิ & : & $\stackrel{m}{=}$ & 范 & $\stackrel{8}{8}$ & $\frac{9}{8}$ & $\frac{m}{5}$ & & ת & \begin{tabular}{|l|l|l|}
$\frac{9}{5}$ & \\
5 & \\
\end{tabular} & \begin{tabular}{l|l} 
\\
\hdashline
\end{tabular} & \begin{tabular}{c|c}
8 & 5 \\
\end{tabular} & 8 & ฐָ & $\frac{7}{2}$ & & 169.9 \\
\hline Final Priorities & & \begin{tabular}{|l|l} 
\\
0 \\
0 \\
0 \\
0
\end{tabular} & & 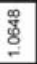 & \begin{tabular}{|l|} 
\\
\\
$\vdots$ \\
0
\end{tabular} & $\begin{array}{l}0 \\
0 \\
0 \\
0\end{array}$ & 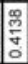 & $\overline{\overline{\dddot{g}}}$ & 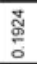 & $\frac{\mathbb{8}}{\stackrel{8}{0}}$ & 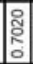 & 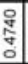 & 第 & 이 & 이 & ( & ปู่ & 产 & & & & \begin{tabular}{|l|l|l|}
$\overline{2}$ \\
0 \\
0
\end{tabular} & 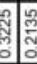 & 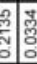 & ; & ס̊: & 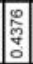 & 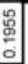 & \\
\hline
\end{tabular}

Fig. (16): DPAM in subsystem design phase

\subsection{Phase 3: Subsystem Requirements}

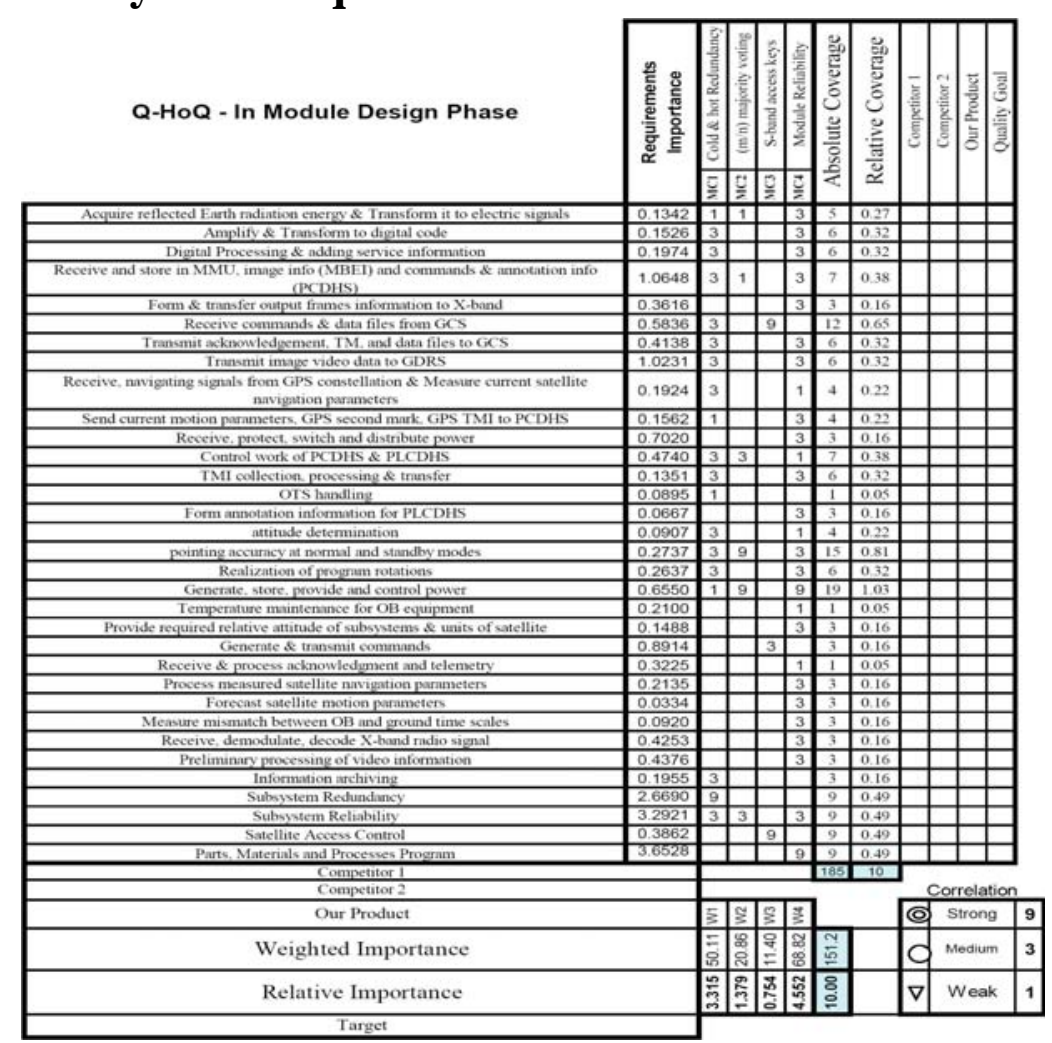

Fig. ( 17): Q-HoQ in module design phase 
An Object-Oriented Software Design Tool Using Automated Hoq And Ahp For Tracing And Prioritizing System Requirements.

Attia and Soliman

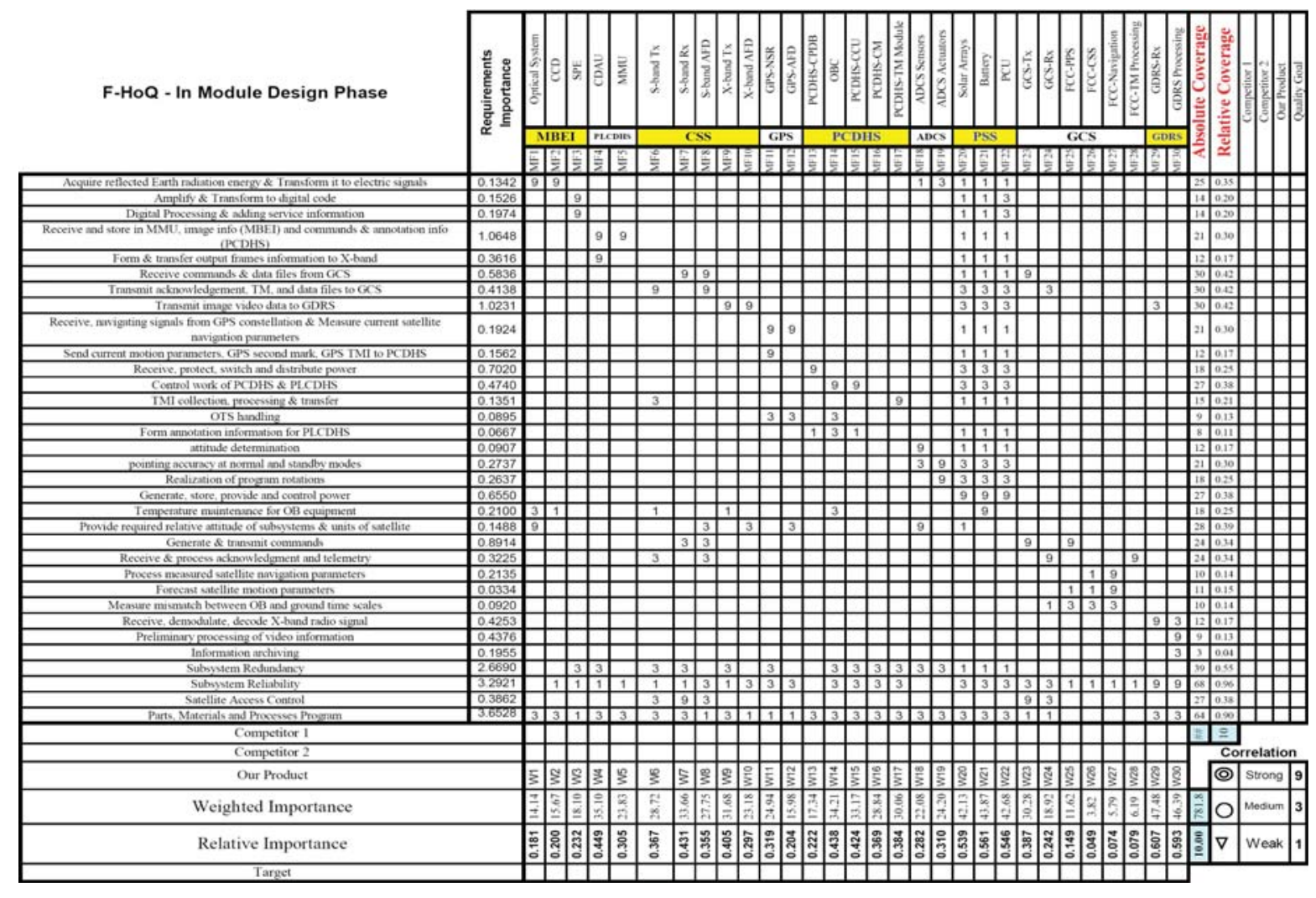

Fig. (18): F-HoQ in module design phase

\section{Resultant Priorities of Module Functions and module constraints}

Table (4): shows the resultant calculated importance or priorities of different module function and module constraints of micro-satellite systems. 
Table (4): module functions priorities

\begin{tabular}{|c|c|c|c|c|}
\hline No & Mod Fn & Function & Priority & Priority Weighted \\
\hline 1 & MF30 & GDRS Processing & 0.623 & 0.5497059 \\
\hline 2 & MF29 & GDRS-Rx & 0.601 & 0.5302941 \\
\hline 3 & MF21 & Battery & 0.531 & 0.4685294 \\
\hline 4 & MF22 & PCU & 0.514 & 0.4535294 \\
\hline 5 & MF20 & Solar Arrays & 0.508 & 0.4482353 \\
\hline 6 & MF4 & CDAU & 0.490 & 0.4323529 \\
\hline 7 & MF14 & $\mathrm{OBC}$ & 0.449 & 0.3961765 \\
\hline 8 & MF7 & S-band Rx & 0.440 & 0.3882353 \\
\hline 9 & MF15 & PCDHS-CCU & 0.435 & 0.3838235 \\
\hline 10 & MF17 & PCDHS-TM Module & 0.397 & 0.3502941 \\
\hline 11 & MF23 & GCS-Tx & 0.395 & 0.3485294 \\
\hline 12 & MF16 & PCDHS-CM & 0.382 & 0.3370588 \\
\hline 13 & MF6 & S-band Tx & 0.381 & 0.3361765 \\
\hline 14 & MF8 & S-band AFD & 0.362 & 0.3194118 \\
\hline 15 & MF5 & MMU & 0.338 & 0.2982353 \\
\hline 16 & MF11 & GPS-NSR & 0.327 & 0.2885294 \\
\hline 17 & MF19 & ADCS Actuators & 0.324 & 0.2858824 \\
\hline 18 & MF9 & X-band Tx & 0.312 & 0.2752941 \\
\hline 19 & MF18 & ADCS Sensors & 0.294 & 0.2594118 \\
\hline 20 & MF24 & GCS-Rx & 0.254 & 0.2241176 \\
\hline 21 & MF3 & SPE & 0.232 & 0.2047059 \\
\hline 22 & MF13 & PCDHS-CPDB & 0.226 & 0.1994118 \\
\hline 23 & MF2 & $\mathrm{CCD}$ & 0.214 & 0.1888235 \\
\hline 24 & MF12 & GPS-AFD & 0.214 & 0.1888235 \\
\hline 25 & MF10 & X-band AFD & 0.201 & 0.1773529 \\
\hline 26 & MF1 & Optical System & 0.197 & 0.1738235 \\
\hline 27 & MF25 & FCC-PPS & 0.152 & 0.1341176 \\
\hline 28 & MF28 & FCC-TM Processing & 0.083 & 0.0732353 \\
\hline 29 & MF27 & FCC-Navigation & 0.074 & 0.0652941 \\
\hline 30 & MF26 & FCC-CSS & 0.050 & 0.0441176 \\
\hline No & Mod Ct & Function & Priority & Priority Weighted \\
\hline 1 & MC4 & Module Reliability & 4.642 & 0.5461176 \\
\hline 2 & MC1 & Cold \& hot Redundancy & 3.209 & 0.3775294 \\
\hline 3 & $\mathrm{MC2}$ & $(\mathrm{m} / \mathrm{n})$ majority voting & 1.386 & 0.1630588 \\
\hline 4 & MC3 & S-band access keys & 0.763 & 0.0897647 \\
\hline
\end{tabular}

The methodology can be extended to the fourth phase of system design (Component Phase). In this case, the priorities of component functions and component constraints can be identified.

Example: // the ADCS is sub1 as shown in Fig. (2)

Module of subsystem ADCS

Components of Actuator

Module (Association)

Different variants of RW

(Inherited from RW)

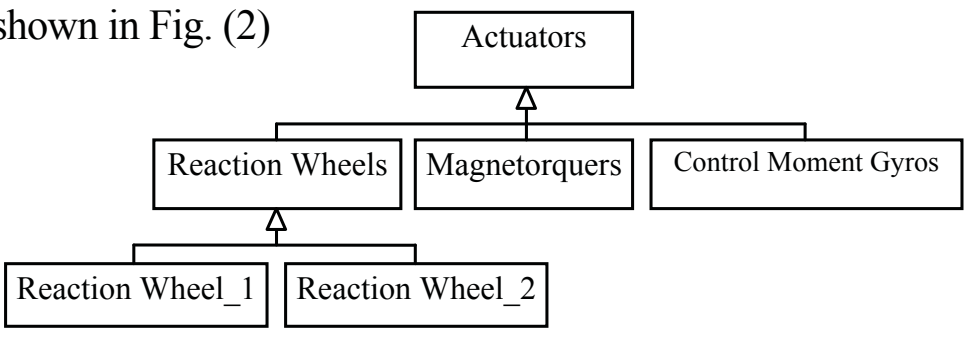


An Object-Oriented Software Design Tool Using Automated Hoq And Ahp For Tracing And Prioritizing System Requirements.

Attia and Soliman

\section{ACRONYMS}

\begin{tabular}{|c|c|c|c|}
\hline MBEI & Multiband Earth Imager & AFD & Antenna Feeder Device \\
\hline CCD & Charge Coupled Devices & S-Tx & S-Band Transmitter \\
\hline MTF & Modulation Transfer Function & S-Rx & S-Band Receiver \\
\hline SPE & Signal Processing Equipment & X-Tx & X-Band Transmitter \\
\hline PLCDHS & Payload Command and Data Handling Subsystem & NSR & Navigation Signal receiver \\
\hline CDAU & Configuration and Data Acquisition Unit & GCS & Ground Control Station \\
\hline MMU & Mass Memory Unit & GDRS & Ground Data Reception Station \\
\hline PCDHS & Platform Command and Data Handling Subsystem & FCC & Flight Control Center \\
\hline CCU & Configuration Control Unit & FCC-PPS & Flight Control Center, Payload Scheduling \\
\hline CPDB & Control and Power Distribution Block & FCC-CSS & Flight Control Center, Control Subsystem \\
\hline CM & Command Module & FCC-NAV & Flight Control Center, Navigation Subsystem \\
\hline TM & Telemetry Module & FCC-TM & Flight Control Center, Telemetry Processing \\
\hline OBC & On Board Computer & PCU & Subsystem \\
\hline CSS & Communication Subsystem & PMP & Parts, Materials and Processes \\
\hline
\end{tabular}

\section{CONCLUSION}

It has been commonly acknowledged that customer requirements are essential in software development to achieve a high level of software quality and customer satisfaction. There are a few methodologies, however, that deal with the traceability of customer requirements through impact analysis throughout the software design process into the design items. The paper proposed a framework that integrates object-oriented software design, which has been a popular paradigm for software development with QFD. The paper major contribution is making the customer requirements traceable from requirements analysis, to system design, subsystem design, and module design so that both customers and software developers can clearly identify whether the important requirements are implemented, and how they are implemented in system design, sub- system design, and module design. In addition, through the methodology, the important requirements can be traced to prioritized design items. With the help of the methodology introduced in this paper, the weights of the requirements and their impacts on the design items are calculated. Design items reflecting more impacts from more important requirements deserve more attention and more resources from software developers. When resources are limited and the choice has to be made on which design items to select for implementation, those with high priority values should be selected. With these design items implemented better, a higher level of customer satisfaction can be achieved than the other design alternatives because more important and more influential requirements have been implemented in the software product before the others. One of the limitations of previous methodologies is that the assignment of correla- 
tion values can be arbitrary and can affect the accuracy of the final results. This problem is solved through using the principles of the Fuzzy set theory and through the collaboration of stakeholders during the assignment of correlation values. Each correlation value should be assigned with consensus from all participating stakeholder representatives. This will, to a great extent, remove the possible bias. In addition, the extra cost spent on the calculation of impact relationships is not negligible when the number of requirements and design items becomes large.

\section{REFERENCES}

1- Nancy R. Mead, Software Engineering Institute, Carnegie Mellon University, 2008, "Requirements Prioritization Case Study Using AHP".

2. Nancy R. Mead, Software Engineering Institute, Carnegie Mellon University, 2008, "Requirements Prioritization, Introduction"

3. Saaty, T. L. The Analytic Hierarchy Process. New York, NY: McGrawHill, 1980.

4. Karlsson, J. "Software Requirements Prioritizing," 110-116. Proceedings of the Second International Conference on Requirements Engineering (ICRE'96). Colorado Springs, CO, April 15-18, 1996. Los Alamitos, CA: IEEE Computer Society, 1996

5. Karlsson, J. \& Ryan, K. "Cost-Value Approach for Prioritizing Requirements." IEEE Software 14, 5 (September/October 1997): 67-74
6. Kanishka Bedi, U21Global, Singapore, 2006," Automating the Quality Function Deployment Ho-use of Quality", U21 Global, Graduate School for Global Leaders.

7. Ming-Chyuan Lin, Chieh-Yuan Tsai, Chao-Chun Cheng, and C. Alec Chang, 2004 "Using Fuzzy QFD for Design of Low-end Digital Camera", (C) 2004 Chaoyang University of Technology, ISSN 1727-2394- International Journal of Applied Science and Engineering - 2004. 2, 3: 222-233

8. Xiaoqing (Frank) Liu, Yan Sun, Praveen Inuganti, and Chandra Sekhar Veera, University of Missouri-Rolla, Yuji Kyoya, Toshiba Corporation, 2007. "A Methodology for Tracing the Requirements in the Object-Oriented Software Design Process Using Quality Function Deployment", SQP VOL. 9, NO. 4/C 2007, ASQ.

9. Akao, Yoji, ed. 1990. Quality function deployment: Integrating customer requirements into product design. Cambridge, Mass.: Productivity Press

10. Liu, X. 2000. Software Quality function deployment. IEEE Potentials (Dec.-Jan.): 14-16

11.Wiley J. Larson, United States Air Force Academy and James R. Wertz, Microcosm, Inc. (C) 1999 Microcosm Press E1 Segundo, California, Seventh Printing, 2005, "Space Mission Analysis and Design" Third Edition.

12. Robert Cecil Martin, Object Mentor Inc., 2002, "UML for Java Programmers"., Prentice Hall, Englewood Cliffs, New Jersey. 